\title{
VALIDATION OF SOME RECENT CHILEANTAXONOMIC NOVELTIES IN ERIOSYCE PHIL. (CACTACEAE)
}

\section{VALIDACIONDE ALGUNAS RECIENTES NOVEDADES TAXONOMICASEN ERIOSYCE PHIL. (CACTACEAE)}

\author{
John M. Watson \\ With the collaboration of H. E. Walter, Casilla 161, Los Andes, Chile. \\ john.anita.watson@gmail.com
}

\begin{abstract}
A. E. Hoffmann \& H. E. Walter (2004) published taxonomic novelties invalidly in the latest edition of their book on Cactaceae in Chile. It also contained an orthographical inaccuracy. All these occur in the genus Eriosyce as revised and expanded by Katterman (1994). They are rectified here with the colaboration of the original authors. Further observations are added about rare and interesting taxa treated in Hoffmann \& Walter.
\end{abstract}

KEYwORDS: ICBN, IPNI, monograph, orthography.

\section{RESUMEN}

En la última edición de su libro sobre Cactáceas en Chile, A. E. Hoffmann \& H. E. Walter (2004), además de un error ortográfico, publicaron incorrectamente algunas novedades taxonómicas del género Eriosyce, tal como fue revisado y aumentado por Katterman (1994), lo que las hace inválidas. Estos se corrigen aquí con la cooperación de los autores originales. Además se agregan otras observaciones acerca de algunos raros e interesantes taxas tratados por Hoffmann \& Walter.

Palabras claves: ICBN, IPNI, monografía, ortografía.

\section{INTRODUCTION}

The second edition of Cactáceas en la flora silvestre de Chile by Hoffmann \& Walter (2004) is an extremely valuable national monograph which incorporates the latestresearch and field observations. It is a radical revision of the first edition, to a large extent following a consensus of leading world authorities, and will surely now become the standard local reference work for the family. Several specialists, including both its authors, also contributed new taxonomy there. Later, a few minor irregularities of citation and dependent procedures were noted, which had mainly arisen due to publication pressures and resultant lack of time for revision. The intention here is to address these small discrepancies with the warranty and contribution of one of the original authors. The data require modification and re-publication in order that the taxonomic changes in question be regarded as valid. Corrected versions do now appear in IPNI (2004) on the internet. However online publication is not admitted by IBCN Article 29.1 (Greuter et al. 2000). In addition, the date and place of publication quoted in IPNI refer to the invalid presentations and should therefore be altered to this source. 
Gayana Bot. 63(1), 2006

\section{VALIDATED TAXONOMIC CHANGES}

The following are corrected versions of taxonomic novelties appearing in Hoffmann \& Walter (op. cit.). Explanations for changes are included. Author citations now conform to obligatory procedures as explained in Watson (date):

Eriosyce taltalensis (Hutchison) Katt. ssp. pygmaea (F.Ritter) Ferryman ex J.M.Watson, comb. et stat. nov.

Basionym: Pyrrhocactus pygmaeus F.Ritter, Taxon 12(1): 32.1963.

SyNONYMS: 18 synonyms are cited in Hoffmann \& Walter (op. cit.), q.v.

ICBN Article 49.1 (Greuter et al., op. cit.) requires that "When a genus or lower rank is altered in rank but retains the final epithet in its name, the author of the earlier, name- or epithet-bearing legitimate name (the author of the basionym) must be cited in parentheses, followed by the name of the author who effected the alteration ... The same holds when a taxon of lower rank than genus is transferred to another genus or species, with or without alteration of rank". The original place of publication of the change in question is Hoffmann \& Walter, op. cit.: 240. The name of F. Ritter was not cited there in parentheses for the new combination, which was therefore invalid.

"A new combination ... must be attributed to the author or authors of the publication in which it appears, although it was ascribed to a different author or to different authors, when no separate statement was made that they contributed in some way to that publication. However, ... authorship as ascribed, followed by 'ex', may be inserted before the the name(s) of the publishing author(s)". ICBN Article 46.4 (Greuter et al., op. cit.). As Roger Ferryman did not contribute directly to the present paper, the latter procedure has been followed here.

Note: The epithet pygmaea for this taxon does not occur as a subspecies in any other combination. Hence a change of status is also involved, as indicated above.

Eriosyce odieri (Lem. ex Salm-Dyck) Katt. ssp. malleolata (F.Ritter) A.E.Hoffm. et H.E.Walter, comb. et stat. nov. var. malleolata.

BAsIonym: Chileorebutia malleolata F.Ritter, Taxon 12(3): 123. 1963.

SyNONYMS: 5 synonyms given in Hoffmann \& Walter.

As with the previous entry, q.v., ICBN Article 49 is infringed in the new taxonomic change by the omission of F. Ritter in parentheses as original author of the basionym.

Note: No synonym of this taxon includes the epithet malleolata as subspecies.

The new rank above therefore also represents a change of status, as indicated. The original publication was in Hoffmann \& Walter, op. cit.: 258.

Eriosyce odieri (Lem. ex Salm-Dyck) Katt. ssp. malleolata (F.Ritter) A.E.Hoffm. et H.E.Walter var. weisseri A. E. Hoffm. et H. E. Walter, var. nov.

A var. malleolata recedit corpore solitario, 3-4 cm crasso; spinis tenuioribus, solum $2 \mathrm{~mm}$ longis; floribus brevioribus, ca $30 \mathrm{~mm}$ longis, rubris, stigmatibus rubris, petalis virga mediae partis purpurea; hilo basaliter obliquo.

Chile, Prov. Antofagasta, Cifuncho. 1987. Adriana Hoffmann s.n. Holotype: SGO.

Named in honour of Dr. Pablo Weisser who discovered and described the new taxon.

ICBN Article 32 (Greuter et al., op. cit.) states that "In order to be validly published, a name of a taxon ... must: ... be effectively published ... on or after the starting-point date of the respective group". In this case the base group taxon for vars. malleolata and weisseri is ssp. malleolata. Since the latter was not validly published in Hoffmann \& Walter (loc. cit.) the varieties are also automatically invalidated, even though their form of presentation was otherwise correct. Nor can a taxon date be validated retrospectively.

It is therefore obligatory to publish again on or after the date that the base subspecies is validified.

Note: The Latin diagnosis and type data from the invalid publication are reproduced here verbatim by one of the original authors. The dedication is also cited again. A full Spanish description may be found in Hoffmann \& Walter (loc. cit.). 
Validation in Eriocyse: WATSON, J.

\section{ORTHOGRAPHY AND FURTHER NOTES}

Although the following taxonomic novelties were not in any way invalid, an obligatory change, an additional qualification, a clarified author citation, and another observation follow:

Eriosyce aspillagae (Söhrens) Katt. ssp. maechlerorum H.E.Walter. Kakteen und andere Sukkelenten 53(10): 261. 2002.

ICBN Article 60.11, Note 3 (Greuter et al., op. cit.) requires that the gender and number of dedicatees be denoted by Latin terminations in conformity with Recommendation 60C, and if known not to be so, are to be corrected orthographically. The epithet appears in Hoffmann \& Walter, op. cit.: 198 as maechleri, but the explanation note clearly states that the dedication refers to two persons, Wendelin Mächler, father and son.

Recommendation $60 \mathrm{C}$ indicates the correct masculine genitive plural termination for surnames ending -er. During a final revision of this text, it was noticed that the abovealteration is now also registered by IPNI (op. cit.).

Eriosyce curvispina (Bertero ex Colla) Katt. var. limariensis (F.Ritter) A.E.Hoffm. et H.E.Walter, comb. et stat. nov.

BAsIOnYM: Pyrrhocactus curvispina F.Ritter, Kakteen in Südamerika, Bd. 3: 956. 1980.

Synonyms: Neoporteria limariensis (F.Ritter) Ferryman. Eriosyce limariensis (F.Ritter) Katt.

Note: In the original presentation (Hoffmann \& Walter, op. cit.: 208) the change of status from species to variety was not signalled as stat. nov.

Copiapoa laui Diers. Kakteen und Andere Sukkulenten 31(12): 362-365. 1980.

Following Anderson (2001), Hoffmann \& Walter (op. cit.: 152), quoted Diers \& Esteves as joint authors of this species. The online reference IPNI (op. cit.) cites
L. Diers as sole author. In fact the latter is correct except that Diers is the valid abbreviated formula (Brummitt \& Powell 1992). Confusion of this sort is best anticipated in any critical work by clear reference to the place and date of the original type description. Copiapoa aphanes Mächler et H.E.Walter. Kakteen und andere Sukkelenten 56(4):

101.2005.

This interesting new species illustrated and described in Hoffmann \& Walter, op. cit.: 124, is now listed electronically by IPNI (op. cit.). It was accepted but still awaiting publication at the date the monograph went to press in 2004.

\section{ACKNOWLEDGMENT}

We are indebted to Alicia Marticorena for raising an important further point on plant name authorship which has been incorporated into the text, and to Ing. Mélica Muñoz for a fundamental amendment.

\section{BIBLIOGRAPHY}

Anderson, E. F. 2001. The cactus family. Timber Press, Portland, Oregon. 776 pp.

Brummitt, R. K. \& C. E. Powell (Eds.). 1992. Authors of plant names. A list of authors of scientific names of plants, with recommended standard forms of their names, including abbreviations. Kew. 732 pp.

Greuter, W., J. McNeill, F. R. Barrie, H. M. Burdet, V. Demoulin., N. T. S. Figueiras, D. H. Nicolson, P. C. Silva, J. E. Skog, P. Rehane, N. J. Turland \& D. L. Hawksworth (Eds.). 2000. Internacional Code of Botanical Nomenclature (Saint Louis Code). Koeltz Scientific Books, Königstein, Germany. 474 pp.

Hoffmann, A. E. \& H. E. Walter. 2004. Cactáceas en la flora silvestre de Chile. Segunda edición. Ediciones Fundación Claudio Gay, Santiago de Chile. 307 pp.

INTERNATIONAL PLANT NAMES INDEX (2004 versión). 2004. Published on the Internet. http://www.ipni.org Viewed February 2, 2006.

Kattermann, F. 1994. Eriosyce (Cactaceae): The genus revised and amplified. David Hunt, 54, Priory Road, Richmond England. 176 pp.

WAtson, J. M. 2006. How to cite botanical authors, with particular reference to the Cactaceae. Publication details. Gayana Botanica 63(1): 128-131. 